\title{
Habitat heterogeneity: importance of salt marsh pools and high marsh surfaces to fish production in two Gulf of Maine salt marshes
}

\author{
Richard A. MacKenzie ${ }^{1,2, *}$, Michele Dionne ${ }^{1}$ \\ ${ }^{1}$ Wells National Estuarine Research Reserve, 342 Laudholm Farm Rd., Wells, Maine 04090, USA \\ ${ }^{2}$ USDA Forest Service Institute of Pacific Islands Forestry, 60 Nowelo St., Hilo, Hawai'i 96720, USA
}

\begin{abstract}
Both permanent high marsh pools and the intertidal surfaces of Spartina patens high marshes in southern Maine, USA, proved to be important habitat for resident mummichog Fundulus heteroclitus production. Manipulations of fish movement onto high marsh surfaces revealed similar growth rates and production among fish that were (1) restricted to pools, (2) had access to known areas of marsh surface, or (3) had free access to the entire marsh. Smaller scale manipulations with marked fish revealed that males with access to the marsh surface accumulated significantly more biomass, often exhibited higher growth rates, and had a 1.6× greater production rate than males restricted to pools. Female production was only slightly higher for fish that could access the marsh compared to fish restricted to pools. While both pools and marsh surface appeared to support fish production, habitat partitioning also existed between sexes of mummichogs; males may rely more on the marsh surface for food while females rely more on pools. Growth and production of mummichogs in pools on the high marsh surface was lower than values reported from more southern, low marsh dominated systems. This was attributed to differences in (1) abiotic factors of salt marsh pools (this study) and tidal creeks and channels (other studies), (2) climate, and (3) tidal inundation and access time to the marsh surface. Fish production on the surface of Gulf of Maine high marsh ecosystems was equivalent to production in adjacent tidal creeks and channels. Thus, the high marsh surface proved to be an important habitat for supporting fish production in this region.
\end{abstract}

KEY WORDS: Secondary production · High salt marsh $\cdot$ Gulf of Maine $\cdot$ Fundulus heteroclitus

\section{INTRODUCTION}

Studies examining the habitat value (e.g. food source, refuge) of salt marshes along the northwestern Atlantic coast have primarily focused on systems south of Cape Cod, Massachusetts, USA (e.g. Weisberg \& Lotrich 1982a, Halpin 1997, Currin et al. 2003). Far less is known about coastal marshes in the state of Maine, which differ in geomorphology, climate, hydrology, and ecology from more southerly systems. Salt marshes in Maine are often exposed to harsh New England winters when ice disturbance (e.g. rafting) can affect sediment deposition (Argow \& Fitzgerald 2006), plant recolonization (Ewanchuk 2003) or inter-specific plant competition (Bertness \& Ewanchuk 2002). Tidal ranges are also much greater (i.e. 3 to $10 \mathrm{~m}$ ), delineating New England marshes into distinct 'high' and 'low' elevational zones, the former being more spatially abundant (Jacobsen et al. 1987). These broad expanses of high marsh are dominated by Spartina patens marsh grass that is only inundated by flood tide levels that rise above the cut banks of marsh channels. Mean monthly sea level can vary by tens of centimeters (Morris et al. 2002) and in the Webhannet River estuary, can lead to variation in frequency of high marsh flooding from $2 \%$ (this study) to $40 \%$ of flood tides (Murphy 1991). In contrast, low marsh zones (dominated by $S$. alterniflora) that are inundated on every flood tide (the domi- 
nant vegetation zone in southern marshes) comprise a much smaller proportion of total vegetated marsh in New England (e.g. $7 \%$ of the Webhannet marsh). Thus, access to the surface of high marshes in New England is reduced for resident and transient nekton compared to low marsh zones, which organisms can access on a daily basis and for longer periods of time due to prolonged submergence.

A dominant landscape feature of Maine's tidal marshes is the extensive presence of salt marsh pools (e.g. $13 \%$ of the salt marsh surface, Dionne 2006). These pools are shallow (i.e. 10 to $30 \mathrm{~cm}$ ), soft-bottomed depressions in the high marsh of variable depth, size, and surface area that retain water during low tides. These habitats are somewhat analogous to sub-tidal marsh creeks, providing an aquatic environment for nekton and benthos (i.e. fishes, crustaceans, other invertebrates) during low tide conditions (Murphy 1991, Deegan et al. 2000) as well as food for nekton or wading birds (Kneib 1986, Erwin 1996).

A fish frequently found in these pools in abundance is the mummichog Fundulus heteroclitus, a resident species common in Atlantic salt marshes (Weisberg \& Lotrich 1982b). These fish are known to access the marsh surface during daytime high tides (Weisberg et al. 1981), where they actively feed on detritus, various benthic macroinvertebrates (Kneib \& Stiven 1978, Kneib 1986), diatoms, and other benthic microalgae (James-Pirri et al. 2001, Currin et al. 2003). While they also forage in sub-tidal areas (e.g. tidal creeks), higher growth rates and gut content indices have been observed in mummichogs with access to the marsh surface (Weisberg \& Lotrich 1982a, Javonillo et al. 1997, Fell et al. 1998). Thus, mummichogs provide an important link or trophic relay between marsh production and nearshore fisheries production as they are an important food source for many juvenile and adult species of fish (Kneib 2000). For example, in a New Jersey salt marsh, mummichogs represented 9 to $23 \%$ of the dry weight in the diet of commercially important striped bass Morone saxatlis (representing $51 \%$ of total fish dry weight) (Tupper \& Able 2000, Nemerson 2001) and 8 to $43 \%$ of the dry weight in the diet of young-of-the-year (YOY) Atlantic croaker Micropogonias undulatus (Nemerson 2001). Given their abundance in Gulf of Maine salt marsh estuaries, mummichogs likely provide a trophic relay in Maine salt marshes as well. However, in these high marsh ecosystems where access to the marsh surface is significantly reduced relative to low marshes, it is not known how salt marsh pools can supplement growth rates or production of fish and therefore contribute to overall salt marsh nekton production.

During the summers of 2002 and 2003, growth rates and secondary production were used to describe energy transfer on the surfaces of salt marshes along the coast of Maine. Mummichog access to the marsh surface during high tides was manipulated to test the hypotheses that (1) fish restricted to pools have positive growth rates and thus secondary production, and (2) that growth rates and secondary production are higher for fish with free access to the marsh surface compared to fish restricted to pools.

\section{MATERIALS AND METHODS}

Site description. The Webhannet River estuary is a marsh-dominated system located within the Wells National Estuarine Research Reserve, $32 \mathrm{~km}$ north of the Maine/New Hampshire border, USA (Fig. 1). This shallow estuary is a tidal inlet that nearly drains at low tide, has a small tidal prism, and a mean tidal range of 2 to $3 \mathrm{~m}$. Freshwater is delivered primarily via the Webhannet River, which drains a $36.5 \mathrm{~km}^{2}$ watershed. The marsh-estuarine system comprises $4.91 \mathrm{~km}^{2}$ of back barrier marsh of which $3.26 \mathrm{~km}^{2}$ is Spartina patens high marsh plain fringed with a $S$. alterniflora low marsh, and $1.43 \mathrm{~km}^{2}$ of intertidal sand and mud.

The Moody marsh is a marsh-dominated system located $26 \mathrm{~km}$ north of the Maine/New Hampshire border.

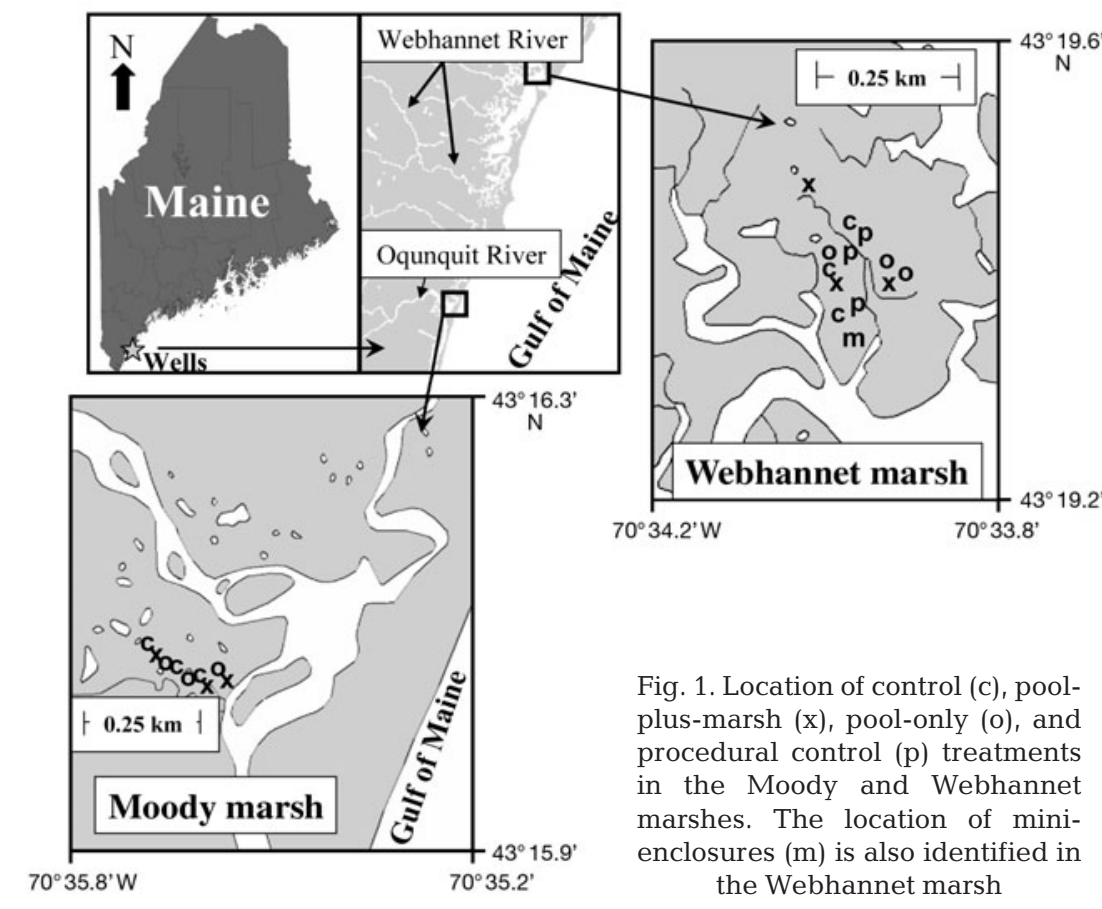


Similar to the Webhannet marsh, this system is located directly behind a back barrier beach, nearly drains at low tide, has a small tidal prism, and a mean tidal range of 2 to $3 \mathrm{~m}$. Freshwater is delivered primarily via the Ogunquit River, which drains a $62.2 \mathrm{~km}^{2}$ watershed. The marsh-estuarine system comprises $0.28 \mathrm{~km}^{2}$ of back barrier marsh of which $0.16 \mathrm{~km}^{2}$ is Spartina patens high marsh plain and fringing $S$. alterniflora low marsh, and $0.12 \mathrm{~km}^{2}$ of intertidal sand and mud.

Physico-chemical parameters. Surface areas of marsh pools and distances between the centers of pools and the main channels were determined from satellite images using ArcView ${ }^{\mathrm{TM}}$. At low tide, average perimeter depths were measured every meter along the outer perimeters of the pools using a meter stick. Dissolved oxygen concentrations, temperatures, and salinities were measured 2 to $4 \mathrm{~cm}$ below the water surface of pools using a YSI ${ }^{\mathrm{TM}}$ dataprobe 85 once a month from June through August only during the 2003 season. Dissolved oxygen concentrations, temperatures, and salinities were also measured every $30 \mathrm{~min}$ over the duration of the study (i.e. 3 mo each year) from the main channel of the Webhannet Marsh using a YSI $^{\text {TM }} 6600$ datasonde. These values were used as a proxy for physico-chemical parameters in tidal creeks and channels adjacent to salt marsh pools.

Connectivity between pools and high marsh surface. Connectivity between marsh pools and the high marsh surface and thus the periods of time fish could access the marsh surface was determined from marsh elevations and water depth measurements. Connectivity was estimated for the duration of the study period (June through August) of both years and only in the Webhannet marsh. Marsh elevations relative to mean sea level (MSL) were measured at each sample pool in the Webhannet Marsh using a Trimble 4800 ${ }^{\mathrm{TM}}$ GPS, visual surveying equipment, and a known National Geodetic Survey benchmark (PID OC0449). Water depth was continually measured relative to MSL every 30 min in the main channel of the Webhannet marsh using a YSI ${ }^{\mathrm{TM}} 6600$ datasonde. For each pool, percent connectivity was determined by dividing the sum of the number of depth readings $\geq$ the marsh elevation surrounding that pool by the total number of depth readings. Average values were then determined for each treatment.

Invertebrate densities. Benthic invertebrates were sampled from Webhannet and Moody marsh pools in June, August, and September 2002 and 2003. Triplicate sediment samples were collected from the bottom of each pool using a mini-Eckman grab. Samples were preserved in $70 \%$ ethanol, stained with Rose Bengal, and sieved through a $500 \mathrm{~mm}$ mesh sieve. Invertebrates were sorted and identified to the lowest practical taxonomic categories. Total invertebrate densities were determined each month by averaging the total number of invertebrates from each replicate and dividing by the area sampled $\left(0.01 \mathrm{~m}^{2}\right)$.

Manipulation of fish movement. Enclosures were constructed around salt marsh pools to manipulate fish movement onto the marsh surface during the growing seasons (June to September) 2002 and 2003. Pools were haphazardly chosen along a tidal creek in the Webhannet ( $\mathrm{n}=12$ ) and Moody marshes ( $\mathrm{n}=9$ ) (Fig. 1). Marsh pools were at similar distances (4 to $6 \mathrm{~m}$ ) from tidal creeks. Three treatments were then randomly established in triplicate in each marsh system: (1) pool-only (fish were restricted to pools during high tide), (2) pool-plus-marsh (fish could access a marsh area surrounding a pool equal to $3 \times$ the pool's surface area), and (3) control (enclosure absent, fish could freely access marsh from pool, and vice versa). Procedural controls were also constructed in triplicate on the Webhannet marsh where enclosures were present but raised $20 \mathrm{~cm}$ off the marsh surface allowing fish access to the marsh surface, allowing testing for artefactual effects of enclosures.

Treatments enclosing natural populations of fish (i.e. non-manipulated) were established during the first week of June. Pool-only enclosures were constructed from rigid $1 \mathrm{~m}$ high, $3 \mathrm{~mm}$ mesh $V_{\text {exar }}^{\mathrm{TM}}$ attached to PVC support poles. The lower edges of the Vexar ${ }^{\mathrm{TM}}$ were attached to sides of pool walls using $20 \mathrm{~cm}$ long landscaping staples, closing off pools so that fish could not leave during high tide. Pool-plus-marsh treatments were constructed by burying the bottom $10 \mathrm{~cm}$ of Vexar $^{\mathrm{TM}}$ in the marsh surface and then attaching to PVC support poles. Procedural controls in the Webhannet marsh were constructed in a manner similar to pool-only treatments, except that the bottom of the mesh was raised $20 \mathrm{~cm}$ from the surface of the marsh. Mesh from all treatments was periodically cleaned with a brush to remove any debris that had accumulated during high tides. To prevent predation by birds, $1 \mathrm{~cm}$ mesh bird netting was placed over each pool.

Fish were sampled once a month from June through August during the first year using 3 to 4 un-baited minnow traps placed in each pool for 30 to $45 \mathrm{~min}$ for mark-recapture density estimates. Because minnow traps inadequately sampled small YOY fish, which make up a major portion of production (Teo \& Able 2003), and because poor recapture rates hindered density estimates, modified lift nets were used from June through August during the second year to sample fish in pools. Lift nets were constructed of $3 \mathrm{~mm}$ mesh, knotless nylon netting that sampled an area of $2.8 \mathrm{~m}^{2}$. Nets were randomly laid at the bottom of the pools for 30 to $45 \mathrm{~min}$, after which they were quickly lifted out of the water. Fish, shrimp, and crabs were then identified, counted, measured to the nearest $\mathrm{mm}$, and weighed to 
the nearest $0.01 \mathrm{~g}$. Density estimates were calculated in 2003 by dividing the total number of fish by the area of the lift net $\left(2.8 \mathrm{~m}^{2}\right)$.

During the summer of 2003, mini-enclosures with controlled fish densities were created in the Webhannet marsh to allow us to track production of individually marked fish. Mini-enclosures were located at equal intervals along the inside edge of a single marsh pool that was located within the same marsh area as the large scale enclosures (Fig. 1). Four pool-only enclosures were constructed out of a PVC pipe frame and $3 \mathrm{~mm}$ mesh Vexar ${ }^{\mathrm{TM}}$, and enclosed a $0.25 \mathrm{~m}^{2}$ area of the pool bottom. Four pool-plus-marsh enclosures were similarly constructed, enclosing a $0.25 \mathrm{~m}^{2}$ area of the pool bottom and $0.75 \mathrm{~m}^{2}$ area of adjacent marsh. Fish densities were determined from data from the previous year and consisted of 4 mummichogs (2 males, 2 females) placed into each enclosure. Males and females were of similar length and weight (males: $47.5 \pm 1.17 \mathrm{~mm}, 1.29 \pm 0.10 \mathrm{mg}$ respectively; females: $50.9 \pm 1.2 \mathrm{~mm}, 1.90 \pm 0.15 \mathrm{mg}$ respectively). Initial weights and lengths were obtained for all fish, which were then individually identified with a subcutaneous injection of Liquitex ${ }^{\mathrm{TM}}$ acrylic artist color latex paint. Latex injections have been successfully used in the past to mark small fish (Sweeney et al. 1998) and a laboratory experiment demonstrated that this technique did not significantly increase fish mortality (Eberhardt 2004). Once a week for $6 \mathrm{wk}$, all fish were removed, remeasured, and re-weighed.

Growth and production rates. For each pool sample, mummichogs were grouped into $10 \mathrm{~mm}$ size classes (e.g. 20 to $29 \mathrm{~mm}$ ) and average biomass was then determined for each class. Monthly growth rates were then calculated for each size class using the exponential model (Chapman 1978):

$$
G_{\text {inst }}=\left(\ln w t_{2}-\ln w t_{1}\right) / t_{2}-t_{1}
$$

where $G_{\text {inst }}$ is instantaneous growth rate, $w t_{2}$ is the average wet weight for size class $n$ measured at time 2 $\left(t_{2}\right)$, and $w t_{1}$ is the average wet weight for size class $n-1$ measured at time $1\left(t_{1}\right)$.

Secondary production was calculated using the cumulative growth method (Chapman 1978):

$$
P=G_{\text {inst }} B
$$

where total production $P$ is equal to the summation of the products of $G_{\text {inst, }}$ and $B$ the mean stock biomass:

$$
B=\left(N_{n-1} w t_{n-1}+N_{n} w t_{n}\right) / 2
$$

where $N_{n-1}$ and $w t_{n-1}$ are the estimates of population size and average wet weights (respectively) of size class $n-1$, and $N_{n}$ and $w t_{n}$ are the population size and average wet weights (respectively) of size class $n$. Production was calculated separately for small YOY mum- michogs $(<40 \mathrm{~mm})$ and for adult and large YOY mummichogs $(>40 \mathrm{~mm})$. Total production was equal to the sum of these 2 groups.

Despite the fact that production was only measured over 3 mo intervals during both years, it was assumed to be an accurate, yet conservative estimate of annual fish production in these marsh ecosystems (biased towards lower values). Feeding activity of mummichogs is significantly reduced during winter months (Fell et al. 1998), which is likely due to decreased water temperatures.

In order to compare results from this study with results from other salt marsh systems, growth and production rates were recalculated using dry biomass of mummichogs. Dry biomass was calculated using a length-weight regression (Bagenal \& Tesch 1978):

$$
\mathrm{DW}=\left(1.24 \times 10^{-6}\right) \times(\mathrm{TL})^{3.22}
$$

where TL was the total length (mm) of the mummichog and DW was dry weight $(\mathrm{g})$. Constants were determined from regressions of dry weight and total length from 60 mummichogs collected from the Webhannet marsh .

Statistics. Physical parameters (i.e. surface concentrations of dissolved oxygen, temperature, salinities), percent connectivity, total invertebrate densities, fish densities, growth rates, and secondary production were first compared between control and procedural control sites in the Webhannet using 1-way analysis of variance (ANOVA) to test for treatment artefacts. If no significant differences were found (e.g. $p \geq 0.25$; Underwood 1997), it was assumed that there were no artefactual effects on fish production from the enclosures, and control and procedural control sites were pooled for comparisons between the Webhannet and Moody sites.

Physical parameters, total invertebrate densities, and fish densities were compared between sites (Webhannet versus Moody) and among treatments (control, pool-plus-marsh, pool-only) using a 3-way factorial ANOVA that accounted for the repeated measures (over time) on each pool. Fixed effects of the model included treatment, site, and date, in addition to all 2-way and 3-way interaction terms.

Because different techniques were used to sample fish in 2002 and 2003, growth rates could not be compared between years. For each year, a 3-way factorial ANOVA was used to compare growth rates, with treatment, site, and each $10 \mathrm{~mm}$ size class as fixed effects. For each year, only size classes with replicate values from all 3 treatments from both the Webhannet and Moody marshes could be compared.

Two-way ANOVAs were performed to examine differences in secondary production, percent contributions to total productivity by small YOY as well as 
adult and large YOY fish, and percent connectivity in the Webhannet marsh. For secondary production and $\%$ contribution to production, main effects included site and pool treatment as fixed factors whose interaction term was estimated. Main effects for hydrologic connectivity (measured only in the Webhannet marsh) included year and treatment as fixed factors, as well as their interaction. Pearson's product moment correlation analysis was used to determine relationships among production, fish densities, and physicochemical parameters. Statistical significances were Bonferroniadjusted to an $\alpha$ value of 0.001 .

Growth rates and changes in biomass for both male and female mummichogs from mini-enclosures were compared between treatments (pool-plus-marsh versus pool-only) using 1-way ANOVAs that accounted for repeated measures on each fish. Production rates from mini-enclosures were compared between treatments and sexes using a 2-way ANOVA.

Total invertebrate densities, fish densities, and production data did not meet assumptions of normality and equal variance and were therefore $\log (x+1)$ transformed prior to analysis. All data presented in tables, figures, and text are the least square means; all normalized data were back transformed and Baskerville corrected. Growth rates from large scale enclosures and total invertebrate densities are reported as averages because least square means could not be calculated from treatments where only a single growth rate was available or where invertebrate densities were missing. The covariance structures for all repeated measures except for minienclosure comparisons were autoregressive of order one (i.e. measurements on the same pool in June were potentially more correlated with July than August). The covariance structure used for mini-enclosure repeated measures was compound symmetry as it provided a better fit to the data. Posthoc analyses were conducted using the Tukey-Kramer method and all statistical analyses were performed in PROC MIXED from SAS 9.1 (2002. SAS Institute, Cary, North Carolina) at an $\alpha$ level of 0.05 .

\section{RESULTS}

\section{Physical parameters}

Mummichog populations in marsh pools were able to access the marsh surface during both years of the study, although percent connectivity between these 2 habitat types was significantly greater in $2003(5.1 \pm 0.7 \%)$ than in $2002(2.3 \pm 0.07 \%)(p<0.05, F=7.62, \mathrm{df}=1,16)$ (Table 1). Percent connectivity could not be determined for the marsh pool where mini-enclosures were established, but was expected to be similar to the large scale treatments due to its proximity to these pools (Fig. 1).

Mummichogs were exposed to similar environmental conditions among the different treatments in the Webhannet and Moody marsh pools, but not between the 2 sites. While pool areas and depths were similar between treatments and sites (Table 1), average dissolved oxygen concentrations, water temperatures, and salinities measured in June, July, and August 2003 were similar only among the different treatments at each site (Fig. 2). Average dissolved oxygen concentrations, water temperatures, and salinities were all significantly higher in the Webhannet Marsh pools than in the Moody Marsh pools ( $\mathrm{p}<0.001, F=27.36$, $\mathrm{df}=1,44 ; \mathrm{p}<0.001, F=97.07, \mathrm{df}=1,13 ; \mathrm{p}<0.001, F=$ 41.85, df $=1,41$, respectively) (Fig. 2). Parameters were not significantly different between control and procedural control treatments and were thus pooled.

In the Webhannet marsh, dissolved oxygen levels were similar between marsh pools and the main channel (Fig. 2). However, water temperatures of marsh pools were nearly $10^{\circ} \mathrm{C}$ warmer than the main channel. Salinities were generally higher in marsh pools than in the main channel, especially in July and August.
Table 1. Mean depth, area, and \% connectivity (least square means \pm SE) from the 3 treatments in the Webhannet and Moody marshes. Values for the Webhannet control treatments were pooled between control and procedural control as there were no significant differences between them. Percent connectivity was determined by dividing the time that the marsh was flooded by the entire study period. Two-way ANOVAs revealed no significant differences in depth and area among treatments or between sites. Different superscripted non-bold letters in a column indicate a significant difference in mean \% connectivity among treatments (Tukey Kramer pairwise comparison, $\mathrm{p}<0.05$ ), while different superscripted bold letters across rows indicate differences in mean percent connectivity between years based on a 2-way ANOVA $(\mathrm{p}<0.05)$

\begin{tabular}{|c|c|c|c|c|}
\hline & \multirow[t]{2}{*}{$\begin{array}{c}\text { Mean } \\
\text { depth }(\mathrm{m})\end{array}$} & \multirow[t]{2}{*}{$\begin{array}{c}\text { Mean } \\
\text { area }\left(\mathrm{m}^{2}\right)\end{array}$} & \multicolumn{2}{|c|}{$\begin{array}{l}\text { Mean \% connectivity } \\
\text { to high marsh }\end{array}$} \\
\hline & & & 2002 & 2003 \\
\hline \multicolumn{5}{|l|}{ Webhannet } \\
\hline Control & $0.28 \pm 0.02$ & $22.7 \pm 4.9$ & $3.2 \pm 1.0$ & $7.1 \pm 1.0^{\mathrm{a}}$ \\
\hline Pool & $0.27 \pm 0.01$ & $18.0 \pm 6.3$ & $2.7 \pm 1.0$ & $5.7 \pm 1.4^{\mathrm{ab}}$ \\
\hline Pool-plus-marsh & $0.28 \pm 0.01$ & $32.8 \pm 6.3$ & $1.0 \pm 1.0$ & $2.5 \pm 1.0^{\mathrm{b}}$ \\
\hline Mean & $0.28 \pm 0.01$ & $24.5 \pm 3.4$ & $2.3 \pm 0.01^{\mathrm{a}}$ & $5.1 \pm 0.01^{b}$ \\
\hline \multicolumn{5}{|l|}{ Moody } \\
\hline Control & $0.30 \pm 0.02$ & $23.5 \pm 6.3$ & na & na \\
\hline Pool & $0.30 \pm 0.02$ & $29.6 \pm 6.3$ & na & na \\
\hline Pool-plus-marsh & $0.28 \pm 0.02$ & $28.6 \pm 1.4$ & na & na \\
\hline Mean & $0.30 \pm 0.01$ & $27.3 \pm 3.6$ & na & na \\
\hline
\end{tabular}




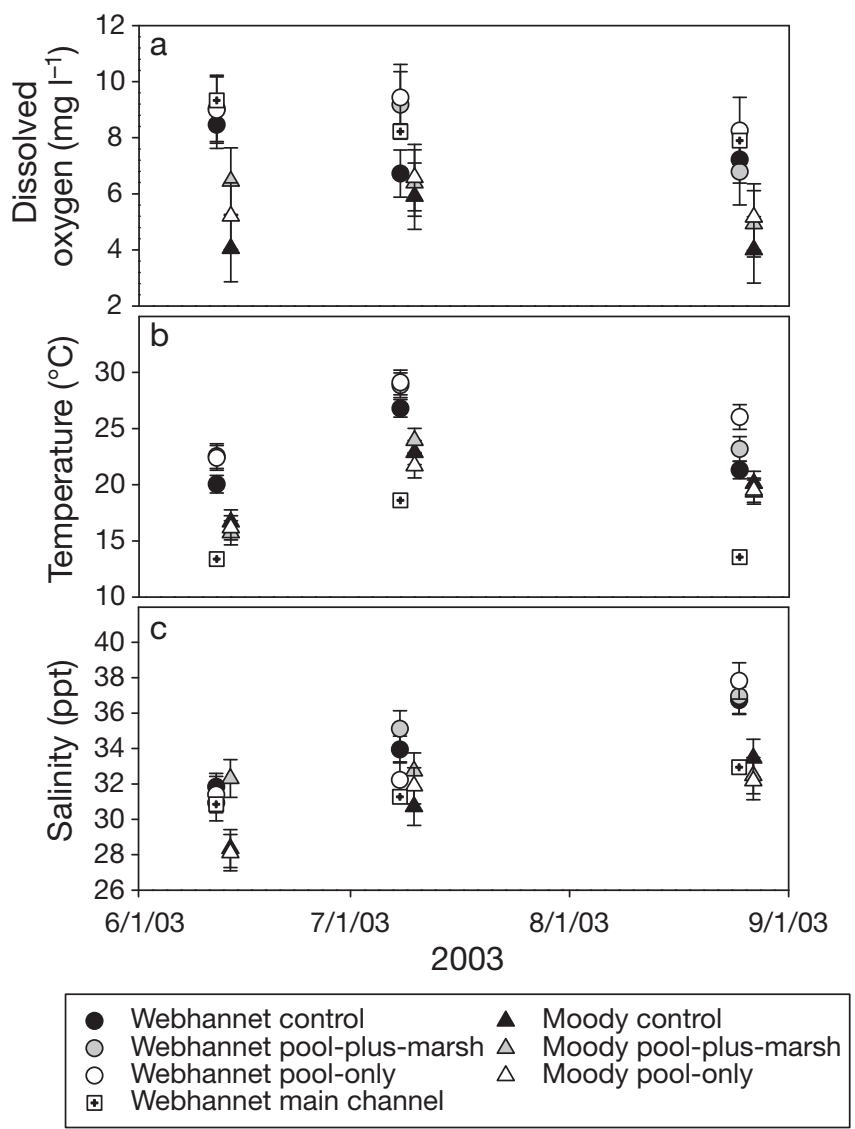

Fig. 2. Monthly patterns of (a) dissolved oxygen, (b) temperature, and (c) salinity from the main channel of Webhannet Harbor ( $\square$ ) and near the surfaces of salt marsh pools in the Webhannet ( $)$ and Moody ( $\boldsymbol{\Delta}$ ) marshes. Values from the control treatments in the Webhannet marsh are pooled values from control and procedural control treatments. Dates are month/day/year. Values are means $\pm \mathrm{SE}, \mathrm{n}=3$ for pool-plusmarsh and pool-only treatments, $\mathrm{n}=6$ for control treatments

\section{Large scale enclosures}

Invertebrate food sources in marsh pools were abundant during the 2002 and 2003 sampling seasons. Although statistical comparisons of total invertebrate densities could not be made in 2002 due to an incomplete data set, densities were generally similar between treatments and months (Fig. 3). In 2003, invertebrate densities were highly variable with no significant differences among treatments, between marshes, or among months sampled (Fig. 3). Invertebrates largely comprised oligochaetes, polychaetes, ostracods, and foraminiferans.

Changes in sampling gear between years resulted in the collection of smaller size classes of fish in 2003. Mummichogs sampled in 2002 from the Webhannet and Moody marshes had average lengths of $46.7 \pm 1.5$ and $48.3 \pm 1.0 \mathrm{~mm}$ and average wet weights of $1.4 \pm 0.1$

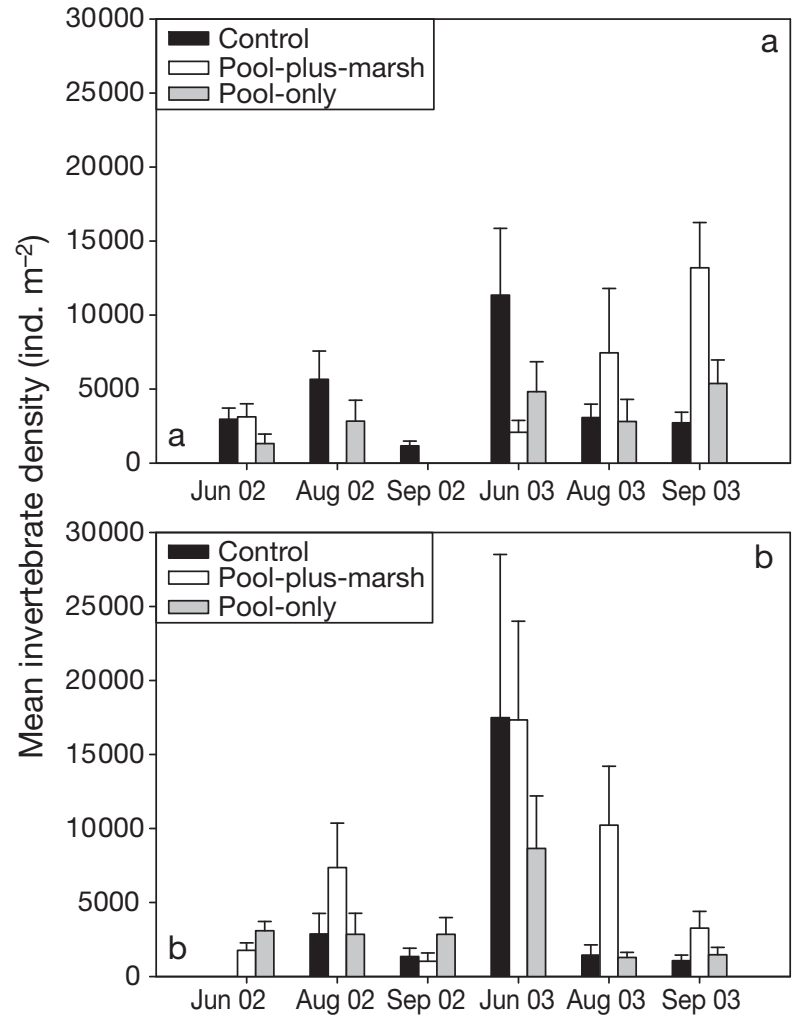

Fig. 3. Mean monthly invertebrate densities (+SE) from the 3 treatments in (a) Webhannet and (b) Moody marshes, 2003. Values for the control treatments in the Webhannet marsh are pooled from control and procedural control treatments. Incomplete data sets are presented for 2002 to show that when comparisons were possible, invertebrate densities were similar between treatments. Missing bars: missing samples

and $1.5 \pm 0.1 \mathrm{~g}$, respectively, over the 3 mo sampling period. In 2003, fish lengths and weights averaged $33.5 \pm 2.2 \mathrm{~mm}$ and $0.40 \pm 0.05 \mathrm{~g}$, respectively, from the Webhannet marsh and $39.9 \pm 1.6 \mathrm{~mm}$ and $0.72 \pm 0.07 \mathrm{~g}$, respectively, from the Moody marsh.

Mummichog densities were similar among all treatments in each month, but statistical comparisons could only be made for 2003 data due to poor recapture rates in 2002. Densities were similar between Webhannet and Moody marsh pools during June and July, but were significantly greater in the Webhannet marsh than in the Moody marsh in August $(p<0.05, F=6.00$, $\mathrm{df}=1,44)$. Densities significantly increased with time in both the Webhannet and Moody marsh pools ( $\mathrm{p}<$ 0.001, $F=46.33$, df = 2, 32) (Table 2). Mean YOY densities were significantly higher in Webhannet marsh pools $\left(44.7 \mathrm{~m}^{-2}, 95 \%\right.$ CL: 30.0, 66.4) than Moody marsh pools $\left(20.5 \mathrm{~m}^{-2}, 95 \%\right.$ CL: 13.1, 32.0) $(\mathrm{p}<0.05, F=7.15$, $\mathrm{df}=1,15)$, while adult densities were similar in Webhannet $\left(8.1 \mathrm{~m}^{-2}, 95 \% \mathrm{CL}: 4.2,14.7\right)$ and Moody marsh pools $\left(9.7 \mathrm{~m}^{-2}, 95 \% \mathrm{CL}: 4.8,18.5\right)$. 
Table 2. Mean fish densities (ind. $\mathrm{m}^{-2}$ ) from 3 treatments in the Webhannet and Moody marshes. Values are backtransformed least square means (lower, upper $95 \%$ confidence interval) with values from the control treatment in the Webhannet marsh pooled from control and procedural control treatments. Different nonbold superscripted letters across a row indicate a significant difference in mean fish density with time, while bold superscripted letters in a column indicate a significant difference in mean fish density between the Webhannet and Moody marshes. Both are based on Tukey-Kramer pairwise comparisons in a 2-way ANOVA $(p<0.05)$

\begin{tabular}{|lccc|}
\hline \multicolumn{2}{c}{ June } & \multicolumn{1}{c|}{ July } & \multicolumn{1}{c|}{ August } \\
\hline Webhannet & & & \\
Control & $1.6(0.5,3.6)$ & $9.7(5.1,17.8)$ & $36.9(20.6,65.5)$ \\
Pool-marsh & $3.1(0.8,8.0)$ & $14.5(6.0,33.2)$ & $38.8(17.0,87.0)$ \\
Pool-only & $1.7(0.2,4.9)$ & $14.5(6.0,33.3)$ & $49.2(21.7,110.1)$ \\
Mean & $2.1(1.0,3.7)^{\mathrm{a}}$ & $12.7(8.0,19.8)^{\mathrm{b}}$ & $41.3(26.8,63.3)^{\mathbf{c a}}$ \\
Moody & & & \\
Control & $3.4(1.0,8.8)$ & $11.1(4.5,25.8)$ & $25.3(10.9,57.3)$ \\
Pool-marsh & $2.4(0.5,6.6)$ & $10.4(4.2,24.2)$ & $15.7(6.5,35.8)$ \\
Pool-only & $5.5(1.9,13.4)$ & $13.8(5.7,31.8)$ & $16.9(7.1,38.6)$ \\
Mean & $3.6(1.9,6.3)^{\mathrm{a}}$ & $11.7(7.0,19.1)^{\mathrm{b}}$ & $18.9(11.6,30.4)^{\mathrm{bb}}$ \\
\hline
\end{tabular}

Mummichog growth rates were similar among all treatments in 2002 and 2003 (Table 3). In 2002, growth rates were similar among the different size classes compared $(45,55,65 \mathrm{~mm})$, but were significantly higher from pools in the Webhannet $(0.032 \pm 0.002 \mathrm{~g}$ wet wt $\mathrm{d}^{-1}$ ) than the Moody marsh pools $(0.022 \pm 0.003)(\mathrm{p}<0.05, F=4.9, \mathrm{df}=1$, 65) (Table 3). In 2003, growth rates in the smaller size classes (25 and $35 \mathrm{~mm}$ ) were significantly higher $(0.028 \pm 0.002$ and $0.025 \pm 0.002 \mathrm{~g}$ wet wt $\mathrm{d}^{-1}$, respectively) than the larger size classes (45 and $65 \mathrm{~mm})(0.018 \pm 0.002$ and $0.021 \pm 0.002 \mathrm{~g}$ wet wt $\mathrm{d}^{-1}$, respectively) (p $<0.01, F=4.60$. df $=3,45)$, but growth rates were similar between

Table 3. Average instantaneous growth rates ( $g$ wet wt $\mathrm{d}^{-1} \pm \mathrm{SE}$ ) for each fish size class from all marsh treatments sampled in 2003 and 2002. Values without SE represent growth rate from a single station. When replicate values were available for all 3 treatments, comparisons of $G_{\text {inst }}$ were made by marsh, treatment, and each size class using 3-way ANOVAs. No significant main effects were found for marsh or treatment

\begin{tabular}{|c|c|c|c|c|c|c|}
\hline $\begin{array}{l}\text { Size class } \\
(\mathrm{mm})\end{array}$ & Control & $\begin{array}{l}\text { Webhannet marsh } \\
\text { Pool-only }\end{array}$ & $\overline{\text { Pool-plus-marsh }}$ & Control & $\begin{array}{l}\text { Moody marsh } \\
\text { Pool-only }\end{array}$ & Pool-plus-marsh \\
\hline \multicolumn{7}{|l|}{8 July 2003} \\
\hline $20-29$ & - & - & - & - & - & - \\
\hline $30-39$ & _- & - & - & _- & _- & _- \\
\hline $40-49$ & - & - & - & - & - & - \\
\hline $50-59$ & $0.021 \pm 0.001$ & - & - & $0.026 \pm 0.003$ & $0.013 \pm 0.001$ & $0.024 \pm 0.002$ \\
\hline $60-69$ & $0.026 \pm 0.001$ & 0.022 & 0.026 & $0.022 \pm 0.006$ & $0.006 \pm 0.003$ & $0.024 \pm 0.003$ \\
\hline $70-79$ & - & 0.033 & - & - & 0.008 & 0.021 \\
\hline $80-89$ & - & - & - & - & - & - \\
\hline \multicolumn{7}{|l|}{25 Aug 2003} \\
\hline $20-29$ & $0.028 \pm 0.005$ & $0.025 \pm 0.003$ & $0.026 \pm 0.001$ & $0.028 \pm 0.004$ & $0.028 \pm 0.002$ & 0.036 \\
\hline $30-39$ & $0.027 \pm 0.005$ & $0.027 \pm 0.003$ & $0.026 \pm 0.003$ & $0.025 \pm 0.002$ & $0.023 \pm 0.003$ & $0.020 \pm 0.001$ \\
\hline $40-49$ & $0.018+0.004$ & $0.019 \pm 0.001$ & $0.021 \pm 0.007$ & $0.017 \pm 0.002$ & $0.020 \pm 0.002$ & 0.017 \\
\hline $50-59$ & - & - & - & $0.012 \pm 0.005$ & 0.014 & 0.008 \\
\hline $60-69$ & - & 0.006 & - & 0.012 & 0.009 & 0.011 \\
\hline $70-79$ & -0.001 & - & - & 0.013 & 0.009 & - \\
\hline $80-89$ & - & - & - & - & 0.007 & - \\
\hline \multicolumn{7}{|l|}{09 July 2002} \\
\hline $30-39$ & - & - & - & - & - & - \\
\hline $40-49$ & - & $0.059 \pm 0.001$ & - & 0.019 & 0.018 & - \\
\hline $50-59$ & $0.026 \pm 0.002$ & $0.031 \pm 0.011$ & $0.046 \pm 0.002$ & $0.021 \pm 0.003$ & $0.022 \pm 0.003$ & 0.025 \\
\hline $60-69$ & $0.041 \pm 0.022$ & $0.030 \pm 0.006$ & $0.042 \pm 0.020$ & $0.032 \pm 0.006$ & $0.036 \pm 0.002$ & 0.033 \\
\hline $70-79$ & 0.020 & - & 0.039 & 0.029 & $0.055 \pm 0.009$ & - \\
\hline \multicolumn{7}{|l|}{25 July 2002} \\
\hline $30-39$ & 0.111 & - & - & - & - & - \\
\hline $40-49$ & - & - & 0.041 & 0.025 & $0.026 \pm 0.005$ & 0.008 \\
\hline $50-59$ & $0.021 \pm 0.010$ & $0.031 \pm 0.003$ & 0.027 & $0.020 \pm 0.005$ & $0.038 \pm 0.005$ & $0.010 \pm 0.002$ \\
\hline $60-69$ & $0.026 \pm 0.003$ & $0.023 \pm 0.005$ & $0.093 \pm 0.068$ & $0.027 \pm 0.006$ & $0.019 \pm 0.004$ & $0.007 \pm 0.001$ \\
\hline $70-79$ & - & 0.020 & 0.020 & - & - & - \\
\hline \multicolumn{7}{|l|}{20 Aug 2002} \\
\hline $30-39$ & $0.048 \pm 0.001$ & $0.048 \pm 0.005$ & - & - & 0.056 & 0.052 \\
\hline $40-49$ & $0.019 \pm 0.003$ & $0.027 \pm 0.006$ & $0.032 \pm 0.012$ & $0.015 \pm 0.003$ & 0.028 & $0.020 \pm 0.008$ \\
\hline $50-59$ & 0.022 & $0.028 \pm 0.006$ & $0.024 \pm 0.009$ & $0.029 \pm 0.005$ & $0.029 \pm 0.001$ & $0.020 \pm 0.002$ \\
\hline $60-69$ & $0.012 \pm 0.005$ & $0.016 \pm 0.001$ & 0.021 & 0.015 & 0.030 & - \\
\hline $70-79$ & 0.020 & 0.010 & - & - & - & - \\
\hline
\end{tabular}


sites. Comparison of all growth rates calculated for 2002 and 2003 (marshes combined) among treatments revealed that growth rates were often highest from pool-only and pool-plus-marsh treatments (Figs. 4 \& 5). Fish less than $40 \mathrm{~mm}$ total length had the highest growth rates.

Total fish production, adult and large YOY production, and small YOY production were not significantly different among treatments or between sites, although production tended to be highest in pool-plus-marsh and pool-only treatments (Fig. 6). YOY production contributed significantly more to total production in the Webhannet marsh $(72.5 \pm 0.07 \%)$ than in the Moody marsh $(46.1 \pm 0.07 \%)(\mathrm{p}<0.05, F=6.96, \mathrm{df}=1,15)$; adult production contributed more to total production in the Moody marsh $(53.9 \pm 0.07 \%)$ than in the Webhannet Marsh $(27.5 \pm 0.07 \%)(\mathrm{p}<0.05, F=6.96$, $\mathrm{df}=1,15)$. Pearson's correlation revealed that total fish production was significantly correlated to YOY fish densities $(r=0.70, p<0.001)$. YOY fish densities were positively correlated to water temperature $(\mathrm{r}=0.59$, $\mathrm{p}=0.004)$ and distance from the main channel $(\mathrm{r}=0.58$,

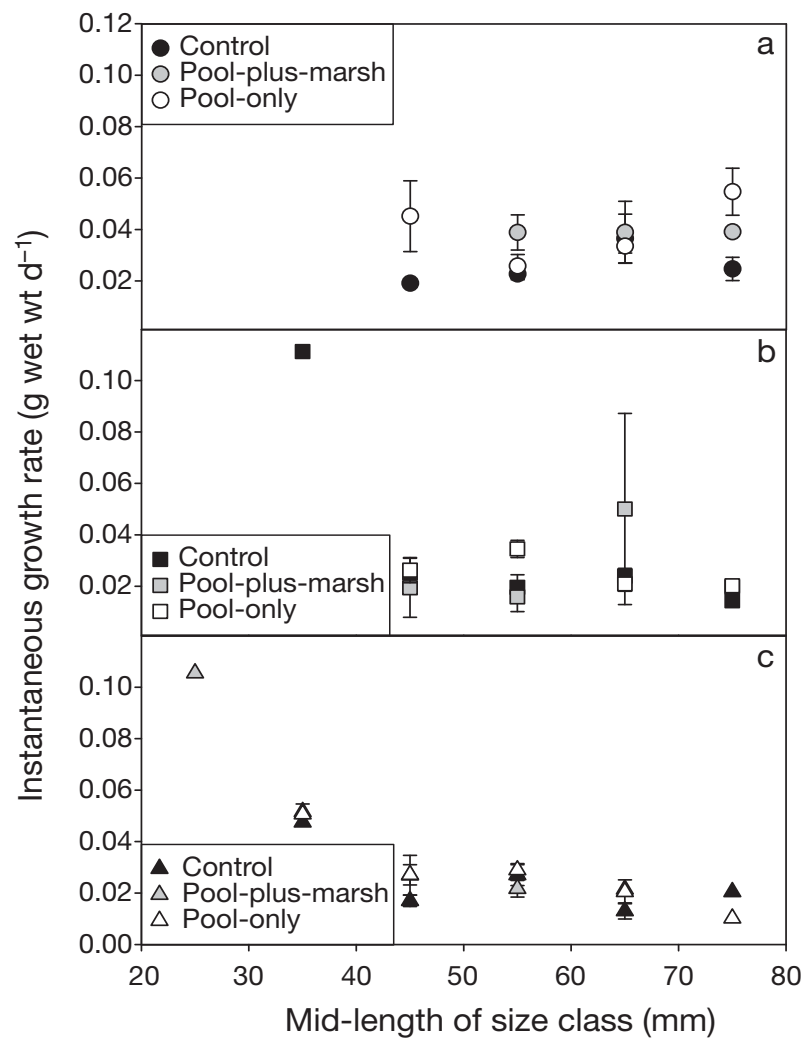

Fig. 4. Average growth rates ( \pm SE) (a) 9 July, (b) 25 July and (c) 25 August 2002 from control, pool-plus-marsh, and poolonly treatments pooled for the Webhannet and Moody marshes. Values from the control treatments in the Webhannet marsh are pooled from control and procedural control treatments. Figures include individual data points that were not included in statistical comparisons

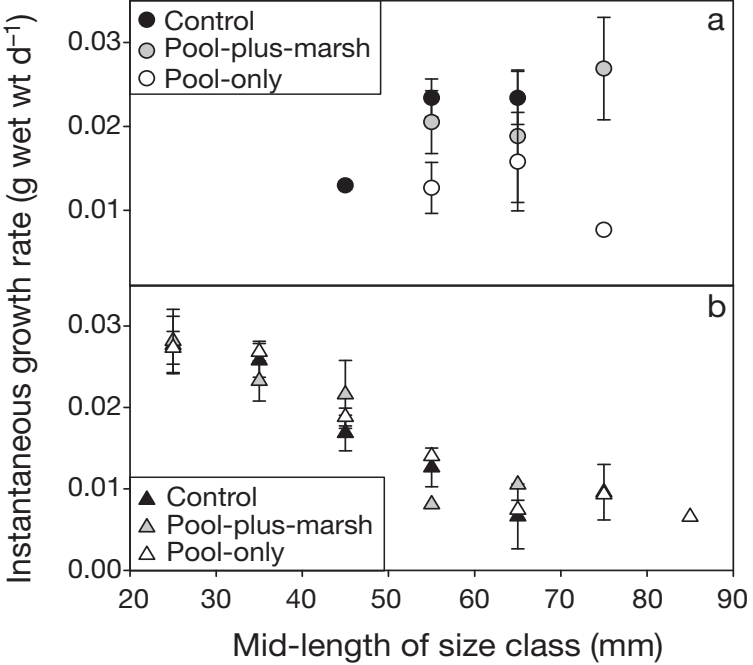

Fig. 5. Average growth rates $( \pm \mathrm{SE})$ (a) 9 July and (b) $25 \mathrm{Au}-$ gust 2003 from control, pool-plus-marsh, and pool-only treatments pooled for the Webhannet and Moody marsh. Values from the control treatments in the Webhannet marsh are pooled from control and procedural control treatments. Figures include individual data points that were not included in statistical comparisons

$p=0.006)$, but were negatively correlated to water depth $(\mathrm{r}=-0.58, \mathrm{p}=0.006)$. Bonferroni adjustments of $\alpha$ values revealed that the latter 3 results were not significant.

\section{Mini-enclosures}

With the exception of 1 of the pool-only treatments, marked fish were successfully recaptured from the mini-enclosures on each of the 5 sampling points. Data from this enclosure were not included in the analyses.

Biomass of female and male mummichogs significantly increased $(\mathrm{p}<0.001, F=44.77, \mathrm{df}=4,32$ and $\mathrm{p}<0.001, F$ $=98.64, \mathrm{df}=4,20$, respectively) in both the pool-only and the pool-plus-marsh mini-enclosures (Fig. 7a). Change in female biomass over time was not significantly different between treatments although wet weights were often greater from pool-plus-marsh than pool-only minienclosures. However, the rate of change in male mummichog biomass over time was significantly higher for the pool-plus-marsh than pool-only mini-enclosures $(\mathrm{p}<0.05, F=4.03, \mathrm{df}=4,20)$ (Fig. 7b).

There were no apparent differences in female growth rates between pool-plus-marsh and the pool-only treatments (Fig. 8a), although growth rates were much lower during the first week. Male growth rates were generally higher in the pool-plus-marsh treatments. However, these differences were not significant (Fig. 8b).

Secondary production of both female and male mummichogs was higher in pool-plus-marsh than 


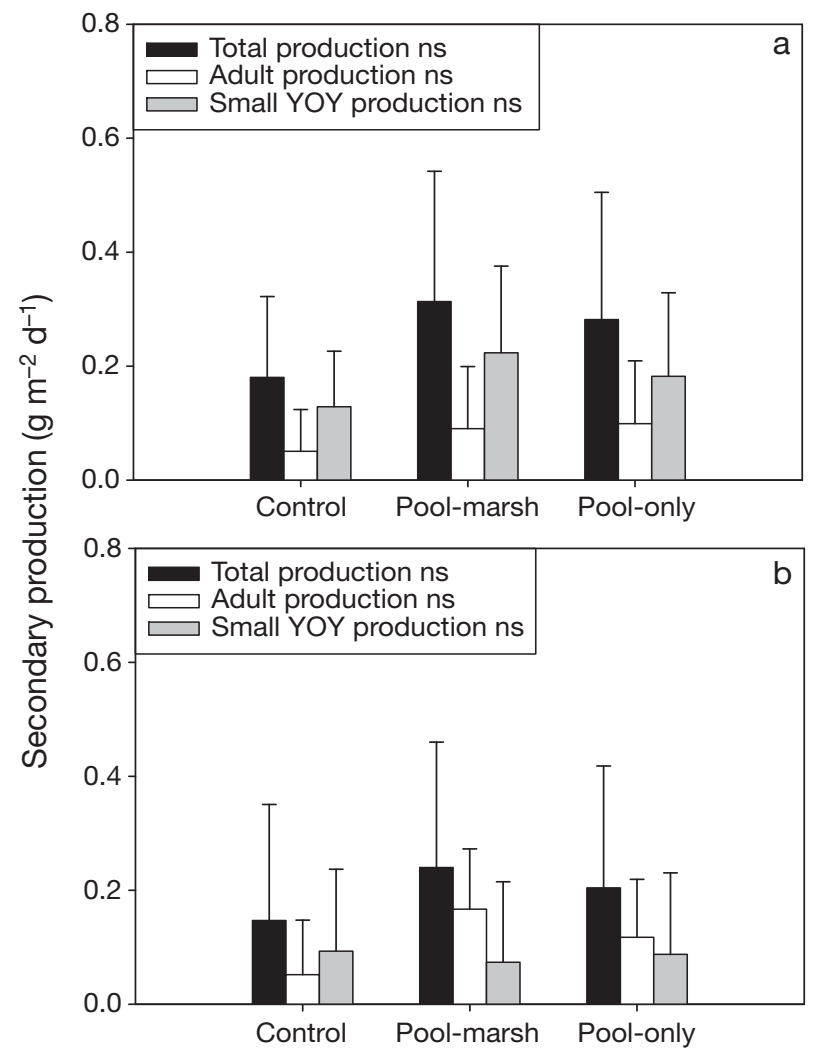

Fig. 6. Mean secondary production estimates from (a) Webhannet and (b) Moody marshes, 2003. Values are backtransformed least square means (+ upper 95\% confidence interval), with values from the control treatment in the Webhannet marsh pooled from control and procedural control treatments. Total production is the sum of adult and small YOY $(<40 \mathrm{~mm})$ production. Adult production includes adult and large YOY (>40 mm) production. There were no significant differences in production between sites or among the three treatments for total, adult, or juvenile production (2-way ANOVA). ns: no signficant difference

pool-only enclosures $\left(0.06 \mathrm{~g} \mathrm{~m}^{-2} \mathrm{~d}^{-1}, 95 \% \mathrm{CL}: 0.04\right.$, 0.08 , and $0.04 \mathrm{~g} \mathrm{~m}^{-2} \mathrm{~d}^{-1}, 95 \% \mathrm{CL}: 0.01,0.07$, respectively, for females; $0.08 \mathrm{~g} \mathrm{~m}^{-2} \mathrm{~d}^{-1}, 95 \%$ CL: 0.05, 0.10, and $0.05 \mathrm{~g} \mathrm{~m}^{-2} \mathrm{~d}^{-1}, 95 \% \mathrm{CL}$ : 0.03, 0.09, respectively, for males) (Fig. 9). While these patterns of production were more pronounced for males, there were no significant differences between treatment or sex and no significant interaction between these 2 factors.

\section{DISCUSSION}

\section{Physical parameters among marsh pools}

Variability in physico-chemical parameters resulted in similar within marsh mean values among different treatments (Fig. 1). Differences in temperatures and salinities between sites were likely due to differences

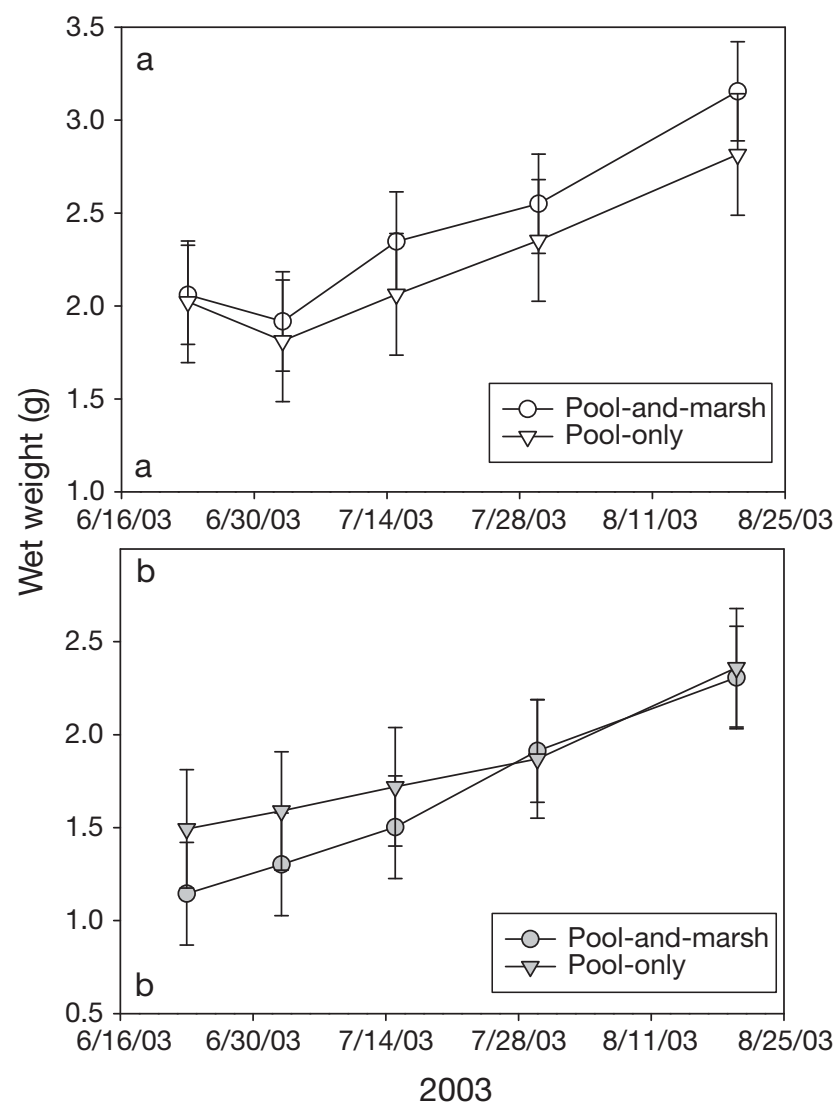

Fig. 7. Mean $( \pm \mathrm{SE})$. Changes in biomass $(g)$ of individually marked (a) female and (b) male mummichogs from minienclosure pool-plus-marsh and pool-only treatments. Dates are month/day/year

in hydrological conditions. Moody marsh pools were closer to heavily developed upland areas than Webhannet marsh pools and likely received increased inputs of surface and groundwater. Runoff may have also lowered dissolved oxygen concentrations in the Moody marsh even though water temperatures were lower than at Webhanet marsh. These freshwater runoff inputs are impounded on the surface of Moody marsh by adjacent drainage ditches recently plugged to flood the marsh for fish and wildlife management.

\section{Fish size and densities}

Interannual differences in fish size and biomass were due to inefficient sampling of smaller size classes by minnow traps. Minnow traps also had low recapture rates of marked fish; densities and production could only be estimated from 2003 lift net data.

Fish densities were similar among all treatments in Webhannet and Moody marshes; densities increased over time in all treatments due to recruitment of YOY 


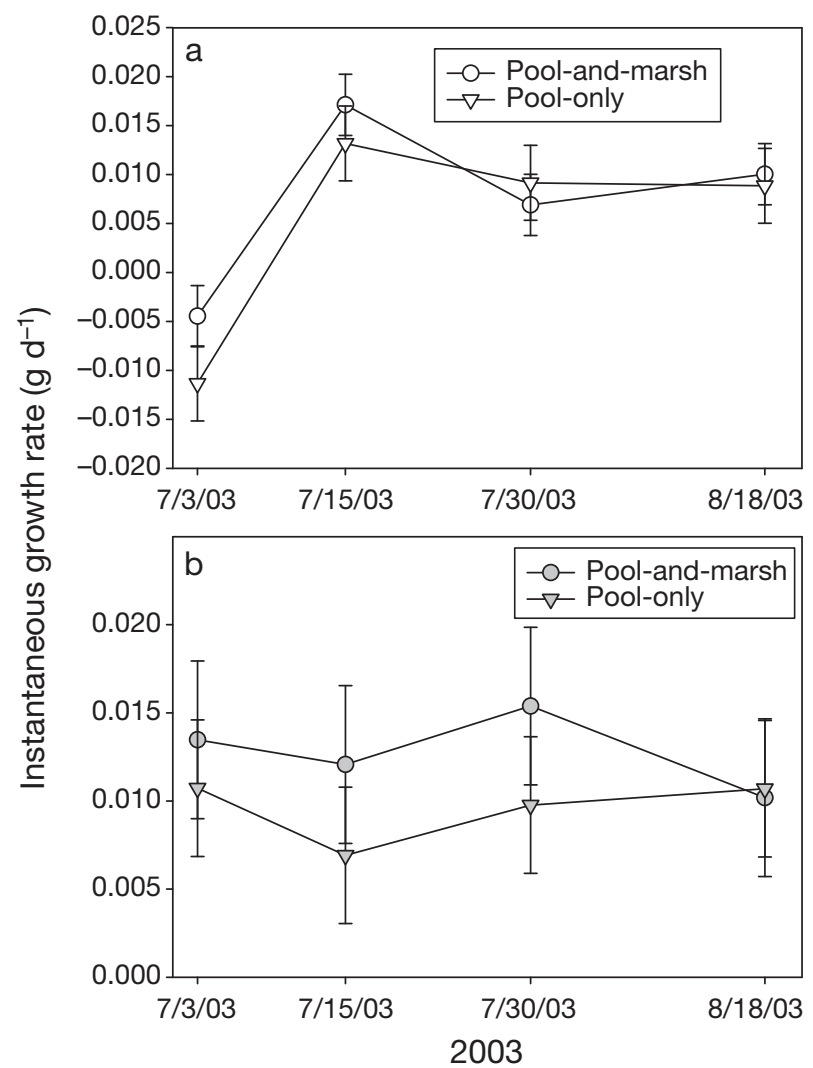

Fig. 8. Mean $( \pm \mathrm{SE})$ instantaneous growth rates $\left(\mathrm{g} \mathrm{d}^{-1}\right)$ of individually marked (a) female and (b) male mummichogs from mini-enclosure pool-plus-marsh and pool-only treatments. Dates are month/day/year

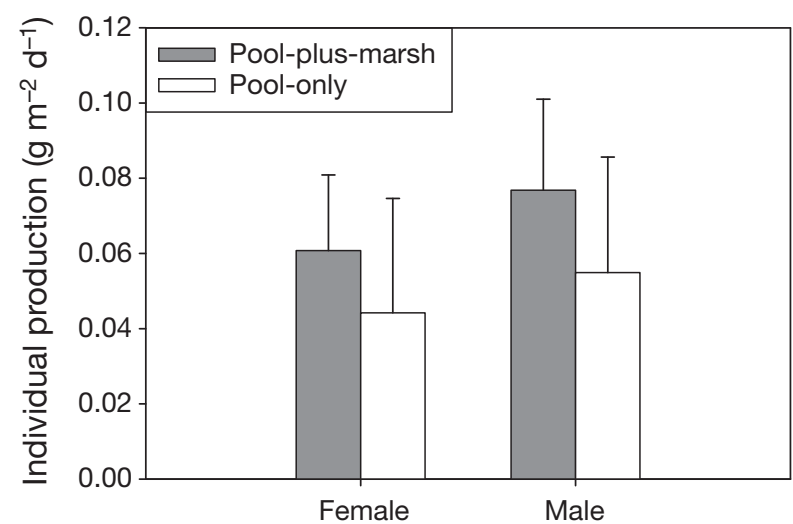

Fig. 9. Mean secondary production $\left(\mathrm{g} \mathrm{m}^{-2} \mathrm{~d}^{-1}\right)$ of individually marked female and male mummichogs from mini-enclosure pool-plus-marsh and pool-only treatments. Values are mean backtransformed least square means + upper 95\% confidence interval

mummichogs. Similar densities among the different treatments revealed that, even though control treatments were open to the marsh-estuarine system, little emigration or immigration of fish occurred from adjacent pools or tidal creeks. An alternative explanation is that numbers of fish immigrating were similar to those emigrating. Site fidelity has been reported for populations of mummichogs in other east coast USA salt marshes. Only $7 \%$ of tagged mummichogs were recaptured outside a marsh pond into which they had been released (Hunter et al. 2007). In other studies, marked mummichogs were recaptured 0 to $5 \mathrm{~m}$ from their release sites (Able et al. 2006) or returned to the site of their original capture after being transported to other areas of the marsh (Lotrich 1975, Eberhardt 2004). Site fidelity is also evident from distinct isotope signatures of mummichogs from different areas within marsh systems (Currin et al. 2003, McMahon et al. 2005).

\section{Growth and production rates}

Variability in physico-chemical parameters among individual marsh pools provided fish with heterogeneous environments. This may have been responsible for the lack of significant differences among growth rates and secondary production among large scale treatments. Similar growth and production rates between large-scale enclosures and open control pools may have also been due to the important sub-tidal habitat provided by marsh pools to resident fish in Maine marshes, where access to the marsh surface is limited to the higher tides. Fish in Webhannet marsh pools were only able to access the high marsh surface 2.3 to $5.0 \%$ of tidal innundations during our study period. Connectivity was not measured in Moody marsh pools, but similar rates of access were assumed to occur based upon observations of tidal flooding on the marsh surface as well as the presence of debris on Vexar mesh around pools. Thus, fish were largely restricted to marsh pools in all treatments during our study period. Similar growth and production rates were likely due to abundant food sources within marsh pools, such as concentrated numbers of shrimp, juvenile mummichogs or benthic macroinvertebrates (Fig. 4). All have been identified as important food sources for mummichogs (Fell et al. 1998, Currin et al. 2003, McMahon et al. 2005). The grass shrimp Palaemonetes pugio was the most abundant organism sampled from Webhannet and Moody marsh pools, with densities often 4 to 7 fold higher than those of Fundulus heteroclitus (authors' unpubl. data). Grass shrimp were commonly found in the guts of mummichogs (authors' pers. obs.) and are known to be an important component in adult mummichog diets (Kneib \& Stiven 1982, Weisberg \& Lotrich 1986, Kneib \& Scheele 2000, Davis et al. 2003). Another important food source that supports mummichog production is benthic microalgal growth on marsh sediments (Creach et al. 1997, Currin et al. 2003), which is more abundant in well lit marsh 
pools than on shaded, vegetated surfaces (Currin et al. 2003).

Comparison of results between mini-enclosures within the same pool may present more accurate results as fish in pool-only and pool-plus-marsh mini-enclosures were exposed to similar environmental conditions. Although fish were largely restricted to marsh pools (see above), male and female mummichogs with access to the marsh surface had 1.6 and $1.5 \times$ higher rates of secondary production, respectively. Males with access to the marsh surface also accumulated biomass at a significantly higher rate and exhibited higher growth rates than male fish restricted to pools. Female mummichogs had similar rates of biomass accumulation and growth in both cage treatments. Thus, results from the mini-enclosures suggest that the Spartina patens marsh surface also provides important habitat for resident fish in Maine, although habitat value may vary between males and females. This may partially explain the between-pool variation in growth and production rates in large-scale enclosures that were not separated by sex. Comparison of stable isotope composition of muscle tissue from mummichogs sampled from a pool adjacent to the study site showed that male mummichogs had significantly lighter $\delta^{13} \mathrm{C}$ and heavier $\delta^{15} \mathrm{~N}$ signatures than females (authors' unpubl. data). Differences in concentrations of heavy metals in tissues from male and female mummichogs have also been reported from polluted marshes (Ferraro et al. 2001). These results all suggest that males and females may be feeding in different areas of the marsh. The larger body size of females compared to males in this species may allow females to monopolize pool resources, leaving males to seek resources on the marsh surface during tidal flooding.

Patterns in secondary production in large-scale enclosures were largely driven by patterns in YOY fish, as reported elsewhere (Kneib \& Wagner 1994, Kneib 2000). For example, small fish represented $>70 \%$ of total mummichog production in a New Jersey salt marsh (Hagan et al. 2007). Comparison of Webhannet and Moody marsh pools revealed that YOY contributed significantly more to total production and fish densities in the Webhannet marsh. Factors responsible for these patterns have not been isolated, but correlations between YOY densities, depth, water temperature, and distance from the main channel suggest that environmental conditions may have been more suitable for YOY mummichogs in Webhannet marsh pools as these systems were warmer and shallower than Moody marsh pools. Because environmental conditions in Moody marsh pools appear to be influenced by human activities, ecological parameters of YOY mummichogs (e.g. densities, production) may provide excellent indicators for how salt marsh systems respond to human activities.

\section{Salt marsh pools as habitat}

Access to the vegetated marsh surface is beneficial to resident fish diets and growth rates. Growth rates and biomass were reduced in mummichogs restricted to tidal creeks in a Delaware marsh (Weisberg \& Lotrich 1982a) and to Massachusetts marsh pools (Javonillo et al. 1997). Similar patterns have been reported for the killifish Fundulus parvipinnis in California salt marshes. Killifish with access to the vegetated marsh surface consumed $6 \times$ as much food as fish restricted to tidal creeks (West \& Zedler 2000), a result supported by a bioenergetics model predicting increased growth rates for F. parvipinnis with access to marsh vegetation (Madon et al. 2001). Our results suggest that, unlike studies conducted in Spartina alterniflora dominated low marsh systems, both marsh pools and surfaces of $S$. patens high marshes are important feeding areas for resident fish and add to overall fish production in southern Maine marshes. While our findings support our hypothesis that fish restricted to pools would have positive growth and production rates, there was only limited support for our hypothesis that the high marsh surface also contributes to these parameters. Further studies allowing fish access to larger areas of high marsh, as well as studies examining linkages between pools and high marsh areas, are needed to better quantify the relative contributions of pool and marsh surface resources to total estuarine productivity.

Comparison of results from this study to others is complicated by differences in location and sampling methods. The upper range of large YOY and adult growth rates recalculated from dry weights for our

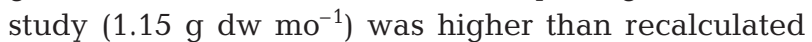
estimates from Massachusetts $\left(0.39 \mathrm{~g} \mathrm{dw} \mathrm{mo}^{-1}\right)$ (Valiela et al. 1977) and Delaware (0.18 g dw mo ${ }^{-1}$ ) (Meredith \& Lotrich 1979) (Table 4). However, the 2 latter values may be underestimates (Teo \& Able 2003). Valiela et al. (1977) used minnow traps that collected adult fish $>60 \mathrm{~mm}$ and excluded smaller size classes that may have higher growth rates (e.g. Figs. 3 \& 4). In Delaware, average densities of different size classes may have been underestimated (Meredith \& Lotrich 1979), which would also underestimate average weights and growth rates. The upper range of growth rates for large YOY and adults from a New Jersey salt marsh (Teo \& Able 2003) were nearly $2 \times$ higher than our estimate. This may be due to the different range of size classes used in New Jersey for large YOY and adults (>30 mm) compared to our study ( $>40 \mathrm{~mm}$ ). However, the highest recalculated growth rate for the 30 to $39 \mathrm{~mm}$ size class in our study was $1.05 \mathrm{~g} \mathrm{dw} \mathrm{mo}^{-1}$, which is $2 \times$ lower than values reported from New Jersey. Thus, mummichog growth and production from southern Maine marsh surfaces appear to be lower than in New Jersey (Table 4). 
Table 4. Comparison of instantaneous growth rates $\left(G_{\text {inst }}\right.$ dry wt $\left.\mathrm{mo}^{-1}\right)$ for small and large YOY and adults, and total, small and large YOY and adult fish production ( $\mathrm{g}$ dry wt $\mathrm{m}^{-2} \mathrm{yr}^{-1}$ ) from this study and from studies conducted in New Jersey, Massachusetts, and Delaware, USA. Instantaneous growth rates from the Webhannet and Moody marshes were recalculated using dry weights

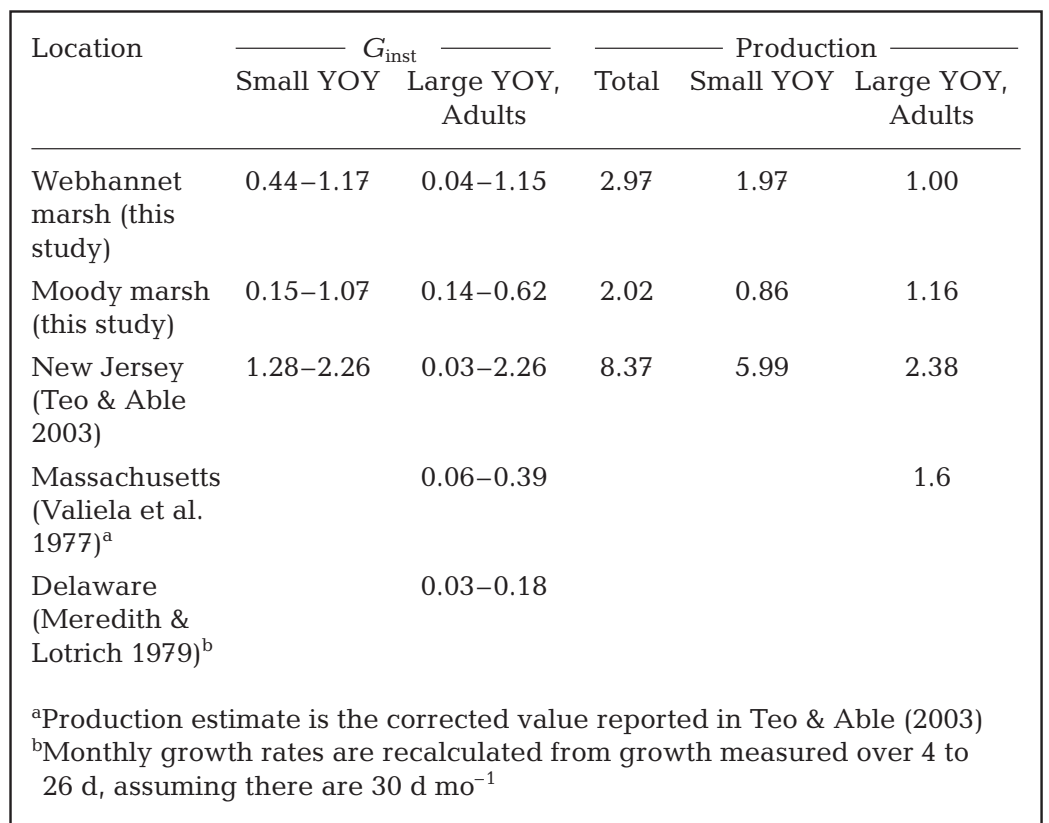

may (or may not) be lower in salt marsh pools, this habitat provides an important energy source to many of the resident and transient nekton species that feed in these ecosystems and likely contribute significantly to overall estuarine productivity in the Gulf of Maine.

\section{Conservation and management implications}

Marsh pools in the Webhannet and Moody marshes provide valuable continually immersed habitat that supports resident fish populations. Even though access to the high marsh surface during the growing season was limited by low frequency of tidal inundation, the high marsh surface is still an important component of resident fish production. In years when pools are more frequently flooded (Murphy 1991), a greater contribution by the high marsh to pool fish production is to be expected. High marsh areas also provide important

Lower production rates could be due to our conservative estimates being made over a 3 mo field season; however, this does not fully account for lower growth rates. Lower water temperatures in Maine marshes, as well as longer and colder winters, and thus shorter growing seasons, could reduce growth rates and production of resident fish. Lower rates could also be due to the fact that mummichogs in marsh pools from this study had reduced foraging time on the high marsh surface compared to the other studies, where similar size classes sampled from tidal creeks and channels (Valiela et al. 1977, Meredith \& Lotrich 1979, Teo \& Able 2003) had daily access to Spartina alterniflora low marsh areas to forage. Alternatively, salt marsh pools may provide sub-optimal habitat for fish production compared to tidal creeks or channels. In a Rhode Island salt marsh, mummichog growth rates were lower from salt marsh pools than in creeks or channels (Halpin 2000), which was attributed to differences in abiotic factors between the 2 types of habitat and thus quality of habitat provided. Direct comparison of fish production in pools and creeks in Maine marshes are needed to determine their relative contributions to secondary marsh production. However, there is nearly twice as much habitat in Maine salt marsh pools compared to tidal creeks and channel (Dionne 2006), which suggests that total fish production within marsh pools may be equal to or greater than production within creeks and channels. Thus, while production and growth rates spawning areas for mummichog populations. Shallow water depths in the interior portions of the high marsh protect developing fry from predation by larger fish. These fry can then colonize marsh pools, as evidenced by the increased numbers reported here in the month of August. The value of the vegetated marsh surface as a feeding area also appears to vary between sexes, with access to the marsh surface benefiting males more than females. Thus, while it is tempting to think that an increase in the number of pools on the marsh surface will increase fish production, it is important to remember that vegetated Spartina patens high marsh areas also play a vital role in the life cycle of resident marsh fish and thus fish production. This is especially true as the creation of marsh pools on the marsh surface through excavation or plugging of mosquito ditches has recently become a popular marsh restoration technique in New England and elsewhere (Adamowicz \& Roman 2005, Koniski et al. 2006). It is not entirely clear how pools created in this way compare to natural pools. It is also unclear how shifts from robust high marsh to stunted low marsh vegetation (Adamowicz \& Roman 2002) or even mud flats (authors' pers. obs.) that occur as a result of raised water tables from ditch plugging might influence fish production. Future marsh management efforts need to maintain a balance between vegetated areas and marsh pools to sustain resident fish populations and the other fauna that rely on them for food sources. 
Acknowledgements. This study was funded by the Maine State Sea Grant College Program at the University of Maine (NOAA grant number NA16RG1034, project number R-0206) and by the G. Ford Wells National Estuarine Research Reserve Postdoctoral Fellowship. The United States Department of Agriculture Forest Service's Institute of Pacific Islands Forestry in Honolulu, Hawaii supported R.A.M. while working on this manuscript. Research was conducted in portions of the Rachel Carson National Wildlife Refuge by permission of the United States Fish and Wildlife Service. We thank E. Brazer Jr., C. Ellis, M. Haas, J. Miller, L. Weintraub, and E. Wilson for their invaluable assistance in the field and the lab. We also thank J. Baldwin for his assistance with the statistical models used in this study.

\section{LITERATURE CITED}

Able KW, Hagan SM, Brown SA (2006) Habitat use, movement, and growth of young-of-the-year Fundulus spp. in southern New Jersey salt marshes: comparisons based on tag/recapture. J Exp Mar Biol Ecol 335:177-187

Adamowicz SC, Roman CT (2002) Initial ecosystem response of salt marshes to ditch plugging and pool creation: experiments at Rachel Carson National Wildlife Refuge (Maine). USGS Patuxent Wildlife Research Center, Narragansett, RI

Adamowicz SC, Roman CT (2005) New England salt marsh pools: a quantitative analysis of geomorphic and geographic features. Wetlands 25:279-288

Argow BA, Fitzgerald DM (2006) Winter processes on northern salt marshes: evaluating the impact of in-situ peat compaction due to ice loading, Well, ME. Estuar Coast Shelf Sci 69:360-369

Bagenal TB, Tesch FW (1978) Age and growth. In: Bagenal T (ed) Methods for assessment of fish production in fresh waters. Blackwell Scientific Publications, Oxford, p 101-136

Bertness MD, Ewanchuk PJ (2002) Latitudinal and climatedriven variation in the strength and nature of biological interactions in New England salt marshes. Oecologia 132:392-401

Chapman DW (1978) Production. In: Bagenal T (ed) Methods for assessment of fish production in fresh waters. Blackwell Scientific Publications, Oxford, p 202-218

> Creach V, Schricke MT, Bertru G, Marriotti A (1997) Stable isotopes and gut analyses to determine feeding relationships in salt marsh macroconsumers. Estuar Coast Shelf Sci 44:599-611

Currin CA, Wainright SC, Able KW, Weinstein MP, Fuller CM (2003) Determination of food web support and trophic position of the mummichog, Fundulus heteroclitus, in New Jersey smooth cordgrass (Spartina alterniflora), common reed (Phragmites australis), and restored salt marshes. Estuaries 26:495-510

Davis JLD, Metcalfe WJ, Hines AH (2003) Implications of a fluctuating fish predator guild on behavior, distribution, and abundance of a shared prey species: the grass shrimp Palaemonetes pugio. J Exp Mar Biol Ecol 293:23-40

Deegan LA, Hughes JE, Rountree RA (2000) Salt marsh ecosystem support of marine transient species. In: Weinstein MP, Kreeger DA (eds) Concepts and controversies in tidal marsh ecology. Kluwer Academic Publishers, Dordrecht, p 333-368

Dionne M (2006) Biological productivity. In: Dionne M, Dalton C, Wilheim H (eds) Site profile of the Wells National Estuarine Research Reserve. Wells National Estuarine Research Reserve, Wells, ME, p 255-266
Eberhardt AL (2004) Fish versus human corridors: the impacts of road culverts on nekton community composition and movement in New England salt marshes. MS thesis, University of New Hampshire, Durham, NH

> Erwin RM (1996) Dependence of waterbirds and shorebirds on shallow-water habitats in the mid-Atlantic coastal region: an ecological profile and management recommendations. Estuaries 19:213-219

Ewanchuk PJ (2003) Recovery of a northern New England salt marsh plant community from winter icing. Oecologia 136:616-626

Fell PE, Weissbach SP, Jones DA, Fallon MA and others (1998) Does invasion of oligohaline tidal marshes by reed grass, Phragmites australis (Cav.) Trin. ex Steud., affect the availability of prey resources for the mummichog, Fundulus heteroclitus L.? J Exp Mar Biol Ecol 222:59-77

Ferraro ML, Kaplan LAE, Leamon J, Crivello JF (2001) Variations in physiological biomarkers among mummichogs collected from Connecticut salt marshes. J Aquat Anim Health 13:246-256

Hagan SM, Brown SA, Able KW (2007) Production of mummichog (Fundulus heteroclitus): response in marshes treated for common reed (Phragmites australis) removal. Wetlands 27:54-67

> Halpin PM (1997) Habitat use patterns of the mummichog, Fundulus heteroclitus, in New England, 1. Intramarsh variation. Estuaries 20:618-625

Halpin PM (2000) Habitat use by an intertidal salt-marsh fish: trade-offs between predation and growth. Mar Ecol Prog Ser 198:203-214

Hunter KL, Fox MG, Able KW (2007) Habitat influences on reproductive allocation and growth of the mummichog (Fundulus heteroclitus) in a coastal salt marsh. Mar Biol 151:617-627

Jacobson HA, Jacobson GL, Kelley JT (1987) Distribution and abundance of tidal marshes along the coast of Maine. Estuaries 10:126-131

James-Pirri MJ, Raposa KB, Catena JG (2001) Diet composition of mummichogs, Fundulus heteroclitus, from restoring and unrestricted regions of a New England (USA) salt marsh. Estuar Coast Shelf Sci 53:205-213

Javonillo R, Deegan LA, Chiaravalle K, Hughes JE (1997) The importance of access to salt-marsh surface to short-term growth of Fundulus heteroclitus in a New England salt marsh. Biol Bull 193:288-289

Kneib RT (1986) The role of Fundulus heteroclitus in salt marsh trophic dynamics. Am Zool 26:259-269

Kneib RT (2000) Salt marsh ecoscapes and production transfers by estuarine nekton in the southeastern United States. In: Weinstein MP, Kreeger DA (eds) Concepts and controversies in tidal marsh ecology. Kluwer Academic Publishers, Dordrecht, p 267-291

Kneib RT, Scheele CEH (2000) Does tethering of mobile prey measure relative predation potential? An empirical test using mummichogs and grass shrimp. Mar Ecol Prog Ser 198:181-190

Kneib RT, Stiven AE (1978) Growth, reproduction, and feeding of Fundulus heteroclitus (L.) on a North Carolina salt marsh. J Exp Mar Biol Ecol 46:89-98

Kneib RT, Stiven AE (1982) Benthic invertebrate responses to size and density manipulations of the common mummichog, Fundulus heteroclitus, in an intertidal salt marsh. Ecology 63:1518-1532

Kneib RT, Wagner SL (1994) Nekton use of vegetated marsh habitats at different stages of tidal inundation. Mar Ecol Prog Ser 106:227-238

Konisky RA, Burdick DM, Dionne M, Neckles HA (2006) A 
regional assessment of salt marsh restoration and monitoring in the Gulf of Maine. Restor Ecol 14:516-525

Lotrich VA (1975) Summer home range and movements of Fundulus heterclitus in a tidal creek. Ecology 56:191-198

Madon SP, Williams GD, West JM, Zedler JB (2001) The importance of marsh access to growth of the California killifish, Fundulus parvipinnis, evaluated through bioenergetics modeling. Ecol Model 136:149-165

McMahon KW, Johnson BJ, Ambrose WG Jr (2005) Diet and movement of the killifish, Fundulus heteroclitus, in a Maine salt marsh assessed using gut content and stable isotope analysis. Estuaries 28:966-973

Meredith WH, Lotrich VA (1979) Production dynamics of a tidal creek population of Fundulus heteroclitus (Linnaeus). Estuar Coast Mar Sci 8:99-118

Morris JT, Sundareshwar PV, Nietch CT, Kjerfve B, Cahoon DR (2002) Responses of coastal wetlands to rising sea level. Ecology 83:2869-2877

Murphy SC (1991) The ecology of estuarine fishes in southern Maine high salt marshes; access corridors and movement patterns. MS thesis, University of Massachusetts, Amherst, MA

Nemerson DM (2001) Trophic dynamics and habitat ecology of the dominant fish of Delaware Bay (USA) marsh creeks. PhD dissertation, Rutgers University, New Brunswick, NJ

Sweeney J, Deegan LA, Garritt RH (1998) Population size and site fidelity of Fundulus heteroclitus in a macrotidal saltmarsh creek. Biol Bull 195:238-239

Teo SLH, Able KW (2003) Growth and production of the

Editorial responsibility: Otto Kinne,

Oldendorf/Luhe, Germany mummichog (Fundulus heteroclitus) in a restored salt marsh. Estuaries 26:51-63

Tupper M, Able KW (2000) Movements and food habits of striped bass (Morone saxatilis) in Delaware Bay (USA) salt marshes: comparison of a restored and a reference marsh. Mar Biol 137:1049-1058

Underwood AJ (1997) Ecological experiments: their logical design and interpretation using analysis of variance. Cambridge University Press, Cambridge

Valiela I, Wright JE, Teal JM, Volkmann SB (1977) Growth, production and energy transformations in the salt-marsh killifish Fundulus heteroclitus. Mar Biol 40:135-144

Weisberg SB, Lotrich VA (1982a) The importance of an infrequently flooded intertidal marsh surface as an energy source for the mummichog, Fundulus heteroclitus: an experimental approach. Mar Biol 66:307-310

Weisberg SB, Lotrich VA (1982b) Ingestion, egestion, excretion, growth, and conversion efficiency for the mummichog, Fundulus heteroclitus (L.). J Exp Mar Biol Ecol 62: 237-249

Weisberg SB, Lotrich VA (1986) Food limitation of a Delaware salt marsh population of the mummichog, Fundulus heteroclitus (L.). Oecologia 68:168-173

Weisberg SB, Whalen R, Lotrich VA (1981) Tidal and diurnal influence on food consumption of a salt marsh killifish Fundulus heteroclitus. Mar Biol 61:243-246

- West JM, Zedler JB (2000) Marsh-creek connectivity: fish use of a tidal salt marsh in southern California. Estuaries 23: $699-710$

Submitted: August 25, 2006; Accepted: April 30, 2008 Proofs received from author(s): September 10, 2008 